\title{
How interpersonal power affects empathic accuracy: differential roles of mentalizing vs. mirroring?
}

\author{
Dario Bombari ${ }^{1,2}$, Marianne Schmid Mast ${ }^{1,2}$, Tobias Brosch ${ }^{2,3}$ and David Sander ${ }^{2,3}$ \\ ${ }^{1}$ Department of Work and Organizational Psychology, University of Neuchâtel, Neuchâtel, Switzerland \\ 2 Swiss Center for Affective Sciences, University of Geneva, Geneva, Switzerland \\ ${ }^{3}$ Laboratory for the Study of Emotion Elicitation and Expression, Department of Psychology, University of Geneva, Geneva, Switzerland
}

\section{Edited by:}

Corrado Corradi-Dell'Acqua,

University of Geneva, Switzerland

Reviewed by:

Oliver C. Schultheiss, Friedrich

Alexander University, Germany

Sylvia A. Morelli, Stanford

University, USA

\section{*Correspondence:}

Dario Bombari, Department of Work and Organizational Psychology,

University of Neuchâtel,

Emile-Argand 11, 2000 Neuchâtel,

Switzerland

e-mail:dario.bombari@gmail.com
Empathic accuracy (EA) - the correct assessment of the affective states and thoughts of a social partner-affects social behavior and the outcome of interpersonal interactions. Growing evidence has shown that interpersonal power of a perceiver affects EA when assessing a target. This picture, however, is not obvious; there is evidence supporting both the idea that power can improve EA or impair it. Moreover, the mechanisms through which high power individuals are more (or less) accurate at reading others' minds are unknown. The present article provides a new perspective on the power-EA link by investigating how two core abilities involved in EA, mentalizing and mirroring, can explain when and how power is related to EA. The inclusion of findings from neuroimaging studies on mentalizing and mirroring adds a cognitive neuroscience perspective to the power-EA research that has traditionally been conducted in a social psychological framework. The extent to which a given EA-test requires mentalizing or mirroring and the way power affects both of them could explain the contrasting findings. In addition, the analysis of the neural substrates of mentalizing and mirroring may provide new insight into the relationship between power and EA.

Keywords: power, empathic accuracy, mentalizing, mirroring, interpersonal sensitivity

\section{INTRODUCTION}

Power affects how people perceive their interaction partners (e.g., high power people perceive social interaction partners as a means to an end) (Magee and Smith, 2013) and how they interact with others (e.g., powerful people assert themselves by talking a lot and interrupting others) (Schmid Mast, 2002; Hall et al., 2005). In this contribution, we refer to power interpersonally, as the degree to which an individual can exert control over another person (Schmid Mast et al., 2009). We focus on the psychological properties of power that can be evoked not only by a real hierarchical relationship, but also simply through cues related to power. Other definitions are sometimes used in the literature. Structural power refers to the hierarchical differences in functions or positions (Ellyson and Dovidio, 1985). Status is a group acknowledgment of respect awarded to a specific individual or can be the power derived from membership in a specific social group (Sidanius et al., 2004). Dominance can reflect both an enduring trait of personality (Ellyson and Dovidio, 1985) or a more transient behavior related to the intention of seeking control over others (Schmid Mast, 2002). Because our review focuses on experimentally manipulated power and its effect on EA, the articles we cite define power in a similar way as we do (i.e., control over other people).

Power does not only affect how others are perceived and acted upon; it also affects the degree to which the assessment of a perceiver is correct (Hall et al., under review). Correct assessment of other people's traits and states is called interpersonal sensitivity or interpersonal accuracy (Hall and Bernieri, 2001; Schmid Mast et al., 2012). One aspect of interpersonal sensitivity is empathy, which has been defined as the ability of a perceiver to recognize, understand, and share the emotions, intentions, and feelings of a target (Zaki et al., 2009). Empathic accuracy (EA) is the correspondence between perceiver's judgments and target's states and feelings (Ickes, 1997; Zaki et al., 2009). In the present paper, we investigate the link between power and EA.

Research shows that high power individuals are better at correctly assessing others' emotions and thoughts (Schmid Mast et al., 2009). However, this finding is not unequivocal in that opposite effects have been documented as well (Galinsky et al., 2006). A recent meta-analysis (Hall et al., under review) revealed a small ( $\mathrm{Mr}=0.07)$ but significant effect showing that high power individuals are more interpersonally accurate than low power individuals. It is noteworthy that the way power was operationalized (i.e., dispositional trait, structural power, or experimentally induced power) had no significant effect on this relationship. The huge heterogeneity of the effect sizes extracted from the literature suggests that there are moderators at work, affecting the power-EA link. One such moderator might be the different accuracy tests which require different skills or are sensitive to different underlying cognitive processes. Interpersonal accuracy tests tend to correlate only weakly, if at all, with each other (Hall, 2001; Zebrowitz, 2001), which corroborates the idea that different tests might require different skills or cognitive processing styles.

The mechanism through which power affects accurate interpersonal perception is unknown. Previous studies found that 
powerful people are more prosocially oriented (Cote et al., 2011) but also less motivated to be accurate (Stevens and Fiske, 2000) and more socially distant (Magee and Smith, 2013). Schmid Mast et al. (2009) showed that feeling respected and proud partially explained the high power individuals' greater EA. The metaanalysis by Hall et al. (under review) showed that trait dominance was related to more interpersonal accuracy when measured as empathic/responsible compared to egoistic/aggressive. Another trait aspect of power that might moderate the power-EA link is the implicit need for power (nPower) (Winter, 1973), which can influence the perceived saliency (Schultheiss and Hale, 2007; Wang et al., 2011) and the motivational response (Schultheiss et al., 2008) toward emotional faces. Since people high in nPower are faster at recognizing emotions (Donhauser et al., under review), it is possible that nPower positively affects EA. These examples of the potential mechanisms linking power to EA do not provide a comprehensive explanation of the contrasting findings mentioned above. This is why we propose a framework that might tie together the results of previous studies.

Historically, two approaches have been put forward to explain how we read other people's minds (Goldman and Sripada, 2005). The "theory-theory" explains mindreading as an extraction of meaning from targets' behavior, mental state, and context. The "simulation theory" instead postulates that we understand others through an internal simulation of their mental state. Although these two approaches have been developed quite independently, neuroimaging studies have shown that indeed EA involves two different mechanisms, mentalizing, and mirroring (Zaki et al., 2009) and in the present article, we aim to discuss their potential role in relation to how power affects EA.

Mentalizing typically means extracting and understanding another person's goals by making inferences about his/her mind state (Amodio and Frith, 2006; Spunt et al., 2011). It relies on the ability to distinguish between one's own mental perspective and that of others (i.e., theory of mind). Mentalizing skills are often tested through false-belief paradigms where participants read short stories about two characters and need to make inferences about others' minds based on the knowledge available to other people. There is evidence (Lieberman, 2010) that the different mentalizing tasks converge in that they all activate one specific brain area, the dorsomedial prefrontal cortex (dmPFC). Other regions (e.g., the temporo-parietal junction and the temporal pole) might be more contingent on task demands. Mirroring typically means simulating the state of the other to understand the content of his/her mind (Zaki and Ochsner, 2012). The rationale is that observing another person activates the corresponding motor and mental representations in the observer, enabling him/her to understand the other's mind (i.e., neural resonance). Mirroring is supposed to rely on the mirror neuron system, which was first discovered in the macaque brain (Gallese et al., 1996). Although the existence of such a system in humans is now quite commonly assumed, the topic is still debated (e.g., Kilner, 2011). According to Lieberman (2010), the mirror system relies on the bilateral posterior ventrolateral PFC and bilateral anterior inferior parietal lobule (IPL). Mirroring is considered a rather automatic, unconscious response based on shared mental representations whereas mentalizing is a rather cognitive aspect of empathy that necessitates an explicit representation of the subjectivity of the social interaction partner (Decety and Jackson, 2004). The two systems cooperate closely, because the mirror system helps provide an early identification of the facial expressions and the mentalizing system processes this input in order to make causal attributions about emotions (Spunt and Lieberman, 2012).

Accuracy in assessing others' emotions has been documented to be related to both of the aforementioned brain systems: regions within the mirror neuron system (i.e., the middle frontal gyrus and the IPL) and areas involved in mentalizing (i.e., the superior temporal sulcus and medial PFC) (Zaki et al., 2009). To the extent that the cues about a target's feelings and thoughts become multimodal and dynamic, concurrent activation of both systems might be crucial (Zaki et al., 2009).

In the present article we propose a new perspective on the relationship between power and EA by bringing together two strands of research that have so far been relatively unconnected: the study of power and interpersonal accuracy from a social psychological point of view and the study of EA and its neural bases from the cognitive neuroscience approach. In particular we argue (i) that different EA tasks might require predominantly mirroring or mentalizing skills, (ii) that power might influence both mentalizing and mirroring, and (iii) that power might affect the flexibility to switch between mentalizing and mirroring skills.

\section{HOW MIRRORING AND MENTALIZING MAY BE DIFFERENTLY INVOLVED IN EA TASKS: A HYPOTHESIS}

Different EA tasks may require a perceiver to infer emotions of others, guess what they are thinking, and understand what their intentions and motives are, among others. Mirroring and mentalizing may differently affect each of these aspects. In this section, we illustrate how the tasks used in the studies assessing EA of high and low power people may require mentalizing or mirroring skills (see Table 1 for a summary of the studies on this topic).

Some studies used simple recognition of facial expression of emotions to assess EA. This is a very simplistic measure of EA that might not take into account its entire complexity. Simple expression recognition might rely more on mirroring than on mentalizing. Indeed, a number of studies (Dimberg et al., 2000; Hess and Blairy, 2001) found that when participants are presented with pictures of emotional expressions, a facial mimicry response, which is supposed to rely on the mirroring system (Catmur et al., 2008; Heyes, 2011), is automatically elicited. Mentalizing might be less critical than mirroring for facial expression recognition. Even though contrasting findings have been reported (Uljarevic and Hamilton, 2013), some studies showed that children with autism can recognize facial expressions as accurately as typically developing children (Castelli, 2005; Rosset et al., 2008). Autistic children typically have impaired mentalizing skills and the fact that they are able to correctly recognize others' emotions suggests that mentalizing may not play a crucial role in emotion recognition.

In studies in which participants are tested in real-time faceto-face interaction settings, one interaction partner infers the other's feelings during the interaction. Even though this is perhaps a more naturalistic way of testing social variables, there is no control of the mimicry response of participants and therefore of 
Table 1 | An overview of the studies investigating the relationship between power and EA.

\begin{tabular}{|c|c|c|c|c|c|c|}
\hline Study & \multicolumn{2}{|c|}{ Power } & Setting & \multicolumn{2}{|c|}{ EA-related assessment } & Main findings \\
\hline $\begin{array}{l}\text { Anderson and Berdahl } \\
\text { (2002)_Study } 1\end{array}$ & Role play & $\begin{array}{l}\text { High vs. low } \\
\text { power }\end{array}$ & $\begin{array}{l}\text { Face-to-face } \\
\text { interaction }\end{array}$ & $\begin{array}{l}\text { Difference between two } \\
\text { people's ratings }\end{array}$ & $\begin{array}{l}\text { Mirroring + } \\
\text { Mentalizing }\end{array}$ & No significant results \\
\hline $\begin{array}{l}\text { Anderson and Berdahl } \\
\text { (2002)_Study } 2\end{array}$ & Role play & $\begin{array}{l}\text { High vs. low } \\
\text { power }\end{array}$ & $\begin{array}{l}\text { Face-to-face } \\
\text { interaction }\end{array}$ & $\begin{array}{l}\text { Difference between two } \\
\text { people's ratings }\end{array}$ & $\begin{array}{l}\text { Mirroring + } \\
\text { Mentalizing }\end{array}$ & $\begin{array}{l}\text { Power improves the } \\
\text { detection of partners' } \\
\text { signals }\end{array}$ \\
\hline $\begin{array}{l}\text { Boucher et al. } \\
\text { (2008)_Study } 1\end{array}$ & Role play & $\begin{array}{l}\text { High vs. low } \\
\text { power }\end{array}$ & $\begin{array}{l}\text { Face-to-face } \\
\text { interaction }\end{array}$ & $\begin{array}{l}\text { Difference between two } \\
\text { people's ratings }\end{array}$ & $\begin{array}{l}\text { Mirroring + } \\
\text { Mentalizing }\end{array}$ & No significant results \\
\hline $\begin{array}{l}\text { Cote et al. } \\
\text { (2011)—Study } 2\end{array}$ & Role play & $\begin{array}{l}\text { High vs. low } \\
\text { power }\end{array}$ & $\begin{array}{l}\text { Computer- } \\
\text { based }\end{array}$ & $\begin{array}{l}\text { Rating of videotaped } \\
\text { interactions }\end{array}$ & $\begin{array}{l}\text { Mirroring + } \\
\text { Mentalizing }\end{array}$ & No significant results \\
\hline $\begin{array}{l}\text { Galinsky et al. } \\
\text { (2006)—Study } 2\end{array}$ & $\begin{array}{l}\text { Priming (recalling } \\
\text { of autobiographical } \\
\text { events) }\end{array}$ & $\begin{array}{l}\text { High vs. low } \\
\text { power }\end{array}$ & $\begin{array}{l}\text { Computer- } \\
\text { based }\end{array}$ & $\begin{array}{l}\text { Consideration of } \\
\text { communication intentions }\end{array}$ & Mentalizing & $\begin{array}{l}\text { Power decreases } \\
\text { perspective taking }\end{array}$ \\
\hline $\begin{array}{l}\text { Galinsky et al. } \\
\text { (2006)_Study } 3\end{array}$ & $\begin{array}{l}\text { Priming (recalling } \\
\text { of autobiographical } \\
\text { events) }\end{array}$ & $\begin{array}{l}\text { High power vs. } \\
\text { control }\end{array}$ & $\begin{array}{l}\text { Computer- } \\
\text { based }\end{array}$ & $\begin{array}{l}\text { Emotion recognition } \\
\text { (DANVA-2) }\end{array}$ & Mirroring & $\begin{array}{l}\text { Power decreases } \\
\text { emotion recognition }\end{array}$ \\
\hline $\begin{array}{l}\text { Gonzaga et al. } \\
\text { (2008)_men }\end{array}$ & Role play & $\begin{array}{l}\text { High, low, and } \\
\text { equal power }\end{array}$ & $\begin{array}{l}\text { Face-to-face } \\
\text { interaction }\end{array}$ & $\begin{array}{l}\text { Correlation between two } \\
\text { people's ratings }\end{array}$ & $\begin{array}{l}\text { Mirroring + } \\
\text { Mentalizing }\end{array}$ & No significant results \\
\hline $\begin{array}{l}\text { Gonzaga et al. } \\
\text { (2008)—women }\end{array}$ & Role play & $\begin{array}{l}\text { High, low, and } \\
\text { equal power }\end{array}$ & $\begin{array}{l}\text { Face-to-face } \\
\text { interaction }\end{array}$ & $\begin{array}{l}\text { Correlation between two } \\
\text { people's ratings }\end{array}$ & $\begin{array}{l}\text { Mirroring + } \\
\text { Mentalizing }\end{array}$ & Power decreases EA \\
\hline $\begin{array}{l}\text { Kunstman and Maner } \\
\text { (2011)—study } 4\end{array}$ & Role play & $\begin{array}{l}\text { High vs. low } \\
\text { power }\end{array}$ & $\begin{array}{l}\text { Face-to-face } \\
\text { interaction }\end{array}$ & $\begin{array}{l}\text { Difference between two } \\
\text { people's ratings }\end{array}$ & $\begin{array}{l}\text { Mirroring + } \\
\text { Mentalizing }\end{array}$ & Power improves EA \\
\hline $\begin{array}{l}\text { Schmid Mast et al. } \\
\text { (2009)_Study } 1\end{array}$ & Role play & $\begin{array}{l}\text { High vs. low } \\
\text { power }\end{array}$ & $\begin{array}{l}\text { Computer- } \\
\text { based }\end{array}$ & $\begin{array}{l}\text { Rating of videotaped } \\
\text { interactions }\end{array}$ & $\begin{array}{l}\text { Mirroring + } \\
\text { Mentalizing }\end{array}$ & Power improves EA \\
\hline $\begin{array}{l}\text { Schmid Mast et al. } \\
\text { (2009)_Study } 2\end{array}$ & $\begin{array}{l}\text { Priming (Word } \\
\text { completion task) }\end{array}$ & $\begin{array}{l}\text { High and low } \\
\text { power, control }\end{array}$ & $\begin{array}{l}\text { Computer- } \\
\text { based }\end{array}$ & $\begin{array}{l}\text { Rating of videotaped } \\
\text { interactions }\end{array}$ & $\begin{array}{l}\text { Mirroring + } \\
\text { Mentalizing }\end{array}$ & Power improves EA \\
\hline $\begin{array}{l}\text { Schmid Mast et al. } \\
\text { (2009)—Study } 3\end{array}$ & $\begin{array}{l}\text { Priming (recalling } \\
\text { of autobiographical } \\
\text { events) }\end{array}$ & $\begin{array}{l}\text { High and low } \\
\text { power, control }\end{array}$ & $\begin{array}{l}\text { Computer- } \\
\text { based }\end{array}$ & $\begin{array}{l}\text { Emotion recognition } \\
\text { (DANVA-2) }\end{array}$ & Mirroring & $\begin{array}{l}\text { Power improves emotion } \\
\text { recognition }\end{array}$ \\
\hline Snodgrass (1985) & Role play & $\begin{array}{l}\text { High vs. low } \\
\text { power }\end{array}$ & $\begin{array}{l}\text { Face-to-face } \\
\text { interaction }\end{array}$ & $\begin{array}{l}\text { Correlation between two } \\
\text { people's ratings }\end{array}$ & $\begin{array}{l}\text { Mirroring + } \\
\text { Mentalizing }\end{array}$ & Power decreases EA \\
\hline Snodgrass (1992) & Role play & $\begin{array}{l}\text { High vs. low } \\
\text { power }\end{array}$ & $\begin{array}{l}\text { Face-to-face } \\
\text { interaction }\end{array}$ & $\begin{array}{l}\text { Correlation between two } \\
\text { people's ratings }\end{array}$ & $\begin{array}{l}\text { Mirroring + } \\
\text { Mentalizing }\end{array}$ & No significant results \\
\hline
\end{tabular}

In the power section, we list how power was manipulated. Role play means the assignment of a participant to a high or low power role in an interaction with a social partner. Priming refers to an implicit manipulation by means of exposure to social cues related to power. In the EA-related assessment section we describe how the components that might influence EA were measured. The setting reports whether EA assessment relied on a face-to-face live interaction or on a computer-based task (e.g., recognition of pictures of emotional expression). In the following column we describe the measure that was used to assess perceivers' behavior. For each study, we report which skills (i.e., mentalizing and/or mirroring) we hypothesize to be predominantly involved in the task that was used. In the last column we report the main finding of the study. 
the involvement of the mirroring system. The mimicry response is contingent upon situational factors (e.g., attitudes toward the social target, type of social interaction) and can influence both EA and perceived power. For instance, competitive interactions decrease the mimicry response (Lanzetta and Englis, 1989; Weyers et al., 2009). This could be relevant because hierarchical interactions might be competitive and the inhibition of facial mimicry can in turn impair emotion recognition (Oberman et al., 2007). Moreover, facial mimicry can also influence perceived power: people who mimic more in an interaction are perceived as more likeable (van Baaren et al., 2009) and therefore may be less dominant because likeability (Farley, 2008) and agreeableness (Lippa and Arad, 1999) are negatively related to perceived dominance.

Yet other paradigms might require mentalizing skills to a higher degree. In a paper by Galinsky et al. (2006, Study 1) participants were asked to draw an E on their foreheads right before a live interaction with a partner. Powerful people were less likely to draw the letter by taking the perspective of the interaction partner. Even though perspective taking is not a measure of EA per se, it has been suggested as a mechanism through which power might hamper accuracy in social judgments. Perspective taking can be considered a more inferential type of thinking and might therefore rely mostly on mentalizing skills. Muscatell et al. (2012) found that lower social status was related to greater activity in the mentalizing system while encoding social information. This might explain why low power people engage more in perspective-taking strategies than high power people.

In many of the studies that use experimental manipulation of power, participants are asked to recall autobiographical events related to power (Galinsky et al., 2006; Schmid Mast et al., 2009). With this type of priming, the strategy participants use to recall the events is not controlled, which may represent a confounding factor. Some participants might choose spontaneously to focus on contextual information of the recalled event, a strategy that would foster mentalizing skills and advantage those participants in subsequent tasks requiring inferential reasoning (e.g., perspective taking). This idea is supported by a neuroimaging study by Morelli et al. (2012), which shows that focusing on the context of an emotional event involves the mentalizing system more than the mirroring system. Instead, people focusing more on their own bodily sensations (e.g., the stress of being powerless) might elicit a mirroring response and therefore be more accurate in a subsequent task requiring mirroring (e.g., simple emotion recognition).

Taken together, differences in the tasks used to assess EA and to manipulate power might contribute to explain the contrasting finding concerning their relationship.

\section{HOW POWER MAY INFLUENCE MENTALIZING}

Construal Level Theory (CLT; Liberman and Trope, 1998) draws on the concept of psychological distance. Distal entities (e.g., events far in time or space or hypothetical) are more remote from direct experience and therefore need a higher level of construal (i.e., the missing information needs to be taken from more proximal entities). CLT makes specific predictions about power and these have also been taken up by the social distance model of power by Magee and Smith (2013). Powerful people should feel more psychological distance and more dissimilar to powerless individuals (Liberman et al., 2007; Magee and Smith, 2013). Indeed a study by Lammers et al. (2012) provided support for this hypothesis by showing that high power primed people were less willing to collaborate with a social partner on a series of games than low power people. There is evidence that when people are judging targets similar to them, a more ventral region in the medial PFC is activated compared to when people are judging targets that are less similar to them (Mitchell et al., 2006). If high power people perceive low power targets as less similar to them, they might show reduced activation in the ventral medial PFC region, but increased activation in the more dorsal region identified by Mitchell et al. (2006), which correspond to an area typically involved in mentalizing. To the extent that the social distance between high and low power individuals increases, the high power individuals might therefore rely more on mentalizing skills to correctly assess others' thoughts and feelings.

It could also be argued that powerless people rely more on mentalizing than powerful people. Fiske's continuum model of power (Fiske and Neuberg, 1990; Goodwin et al., 2000) predicts that low power people focus their attention on high power people, whereas the latter are more self-focused. A meta-analysis by Denny et al. (2012) showed that a more ventral region of the medial PFC is associated with self-related judgments, whereas a more dorsal region is related to judgments about others. The dmPFC activation suggests mentalizing and indeed its activity is greater in low than high social status people when encoding social information (Muscatell et al., 2012). Further experimental research is therefore necessary in order to specifically test the effects of power on mentalizing.

\section{HOW POWER MAY INFLUENCE MIRRORING}

Studies on facial mimicry can support the hypothesis of an influence of power on mirroring. Theories of embodied cognition claim that emotion recognition is achieved through an internal simulation of the perceived expression (Goldman and Sripada, 2005; Niedenthal et al., 2010). Even though mimicry might not be strictly necessary for emotion recognition (Hess and Blairy, 2001; Sander et al., 2007; Rives Bogart and Matsumoto, 2010; Mumenthaler and Sander, 2012), mimicry responses predict the perceived intensity of facial expressions (Sato et al., 2013). Moreover, interfering with mimicry can hamper emotion recognition accuracy (Oberman et al., 2007; Neal and Chartrand, 2011). Research on mimicry is important if we consider that high power individuals tend to be more expressive than low power people in live interactions (Snodgrass et al., 1998). Hsee et al. (1990) found that powerful individuals are more likely to display subordinate's feelings than vice versa. These findings suggest that high power people might engage the mirroring system to a higher degree than low power people when reading others' minds and this might explain their high accuracy on facial expression recognition tests (Schmid Mast et al., 2009, Study 3). In addition, one could argue that low power people mimic less because they might have more negative mood or attitudes (e.g., toward superiors) and this is known to reduce the mimicry response (Likowski et al., 2011). Again, further experimental research is necessary in order to test the effects of power on mirroring. 


\section{POWER AND FLEXIBILITY}

Hirsh et al. (2011) proposed a model that draws on Keltner et al. (2003) explanations of approach and inhibition. According to these authors, powerful people would be more approachoriented. This would activate the Behavioral Approach System, which in turn would decrease the conflict between competing responses (i.e., disinhibition). Thus, powerful people would behave according to their most salient response, which can be externally driven, when strong contextual cues are present, or internally driven, in absence of such cues. When the response is internally triggered, power can reveal the internal dispositions of the person. When there are strong contextual cues, Hirsh et al.'s model predicts that powerful people will be more responsive to the affordances required by the task. This is in accordance with the Situated Focus Theory by Guinote (2007), which posits that power fosters the attunement to the situation and increases flexibility. Thus, this suggests that powerful people may be more

\section{REFERENCES}

Amodio, D. M., and Frith, C. D. (2006). Meeting of minds: the medial frontal cortex and social cognition. Nat. Rev. Neurosci. 7, 268-277. doi: 10.1038/nrn1884

Anderson, C., and Berdahl, J. L. (2002). The experience of power: examining the effects of power on approach and inhibition tendencies. J. Pers. Soc. Psychol. 83, 1362-1377. doi: 10.1037/0022-3514.83.6.1362

Boucher, E. M., Hancock, J. T., and Dunham, P. J. (2008). Interpersonal sensitivity in computer-mediated and face-to-face conversations. Media Psychol. 11, 235-258. doi: $10.1080 / 15213260801906471$

Castelli, F. (2005). Understanding emotions from standardized facial expressions in autism and normal development. Autism 9, 428-449. doi: $10.1177 / 1362361305056082$

Catmur, C., Gillmeister, H., Bird, G., Liepelt, R., Brass, M., and Heyes, C. (2008). Through the looking glass: counter-mirror activation following incompatible sensorimotor learning. Eur. J. Neurosci. 28, 1208-1215. doi: 10.1111/j.1460-9568.2008.06419.x

Cote, S., Kraus, M. W., Cheng, B. H., Oveis, C., van der Lowe, I., Lian, H., et al. (2011). Social power facilitates the effect of prosocial orientation on empathic accuracy. J. Pers. Soc. Psychol. 101, 217-232. doi: 10.1037/a0023171

Decety, J., and Jackson, P. L. (2004). The functional architecture of human empathy. Behav. Cogn. Neurosci. Rev. 3, 71-100. doi: $10.1177 / 1534582304267187$

Denny, B. T., Kober, H., Wager, T. D., and Ochsner, K. N. (2012). A metaanalysis of functional neuroimaging studies of self- and other judgments reveals a spatial gradient for mentalizing in medial prefrontal cortex. J. Cogn. Neurosci. 24, 1742-1752. doi: 10.1162/jocn_a_00233

Dimberg, U., Thunberg, M., and Elmehed, K. (2000). Unconscious facial reactions to emotional facial expressions. Psychol. Sci. 11, 86-89. doi: 10.1111/1467-9280.00221

Ellyson, S. L., and Dovidio, J. F. (1985). "Power, dominance, and nonverbal behavior: basic concepts and issues," in Power, Dominance, and Nonverbal Behavior, eds S. L. Ellyson and J. F. Dovidio (New York, NY: Springer), 1-27. doi: 10.1007/978$1-4612-5106-4$

Farley, S. (2008). Attaining status at the expense of likeability: pilfering power through conversational interruption. J. Nonverbal Behav. 32, 241-260. doi: 10.1007/s10919-0080054-x

Fiske, S. T., and Neuberg, S. L. (1990). "A continuum of impression formation, from category-based to individuating processes: influences of information and motivation on attention and interpretation," in Advances in Experimental Social Psychology, Vol. 23, ed M. P. Zanna (New York, NY: Academic Press), $1-74$.

Galinsky, A. D., Magee, J. C., Inesi, M. E., and Gruenfeld, D. H. (2006). Power and perspectives not taken. Psychol. Sci. 17, 1068-1074. doi: 10.1111/j.1467-9280.2006.01824.x

Gallese, V., Fadiga, L., Fogassi, L., and Rizzolatti, G. (1996). Action recognition in the premotor cortex. Brain 119(Pt 2), 593-609. doi: 10.1093/brain/119.2.593

Goldman, A. I., and Sripada, C. S. (2005). Simulationist models

able to switch flexibly between mentalizing and mirroring skills, according to what is more relevant to task demands.

\section{CONCLUSIONS}

Whereas current models of power do not seem to properly account for the heterogeneity found in the literature on the power-EA link, in the present paper we speculate that a focus on the differential role of mirroring vs. mentalizing could. This approach can guide future research in at least two directions. First, empirical studies might test specific hypotheses based on the mechanisms we propose here. We expect that the ambivalent effects of power on EA will be teased apart once the effects of mirroring and mentalizing on power and EA are taken into account. Second, future studies might be more cautious in the choice of the specific EA tasks. Indeed, assessing EA through tasks focusing mostly on mirroring or on mentalizing might dramatically influence the outcomes of a study.

of face-based emotion recognition. Cognition 94, 193-213. doi: 10.1016/j.cognition.2004.01.005

Gonzaga, G. C., Keltner, D., and Ward, D. (2008). Power in mixed-sex stranger interactions. Cogn. Emot. 22, 1555-1568. doi: 10.1080/02699 930801921008

Goodwin, S. A., Gubin, A., Fiske, S. T., and Yzerbyt, V. Y. (2000). Power can bias impression processes: stereotyping subodinates by default and by design. Group Process. Intergroup Relat. 3, 227-256. doi: $10.1177 / 1368430200003003001$

Guinote, A. (2007). Behaviour variability and the situated focus theory of power. Eur. Rev. Soc. Psychol. 18, 256-295. doi: $10.1080 / 10463280701692813$

Hall, J. A. (2001). "The PONS Test and the psychometric approach to measuring interpersonal sensitivity," in Interpersonal Sensitivity: Theory and Measurement, eds J. A. Hall and F. J. Bernieri (Mahwah, NJ: Lawrence Erlbaum Associates), 143-160.

Hall, J. A., and Bernieri, F. J. (eds.). (2001). Interpersonal Sensitivity: Theory and Measurement. Mahwah, NJ: Lawrence Erlbaum Associates.

Hall, J. A., Coats, E. J., and Smith LeBeau, L. (2005). Nonverbal behavior and the vertical dimension of social relations: a meta-analysis. Psychol. Bull. 131, 898-924. doi: 10.1037/0033-2909.131.6.898

Hall, J. A., Rosip, J. C., Smith LeBeau, L., Horgan, T. G., and Carter, J. D. (2006). Attributing the sources of accuracy in unequal-power dyadic communication: who is better and why? J. Exp. Soc. Psychol. 42, 18-27. doi: 10.1016/j.jesp.2005.01.005

Hess, U., and Blairy, S. (2001). Facial mimicry and emotional contagion to dynamic emotional facial expressions and their influence on decoding accuracy. Int. J. Psychophysiol. 40, 129-141. doi: 10.1016/S01678760(00)00161-6

Heyes, C. (2011). Automatic imitation. Psychol. Bull. 137, 463-483. doi: 10.1037/a0022288

Hirsh, J. B., Galinsky, A. D., and Zhong, C.-B. (2011). Drunk, powerful, and in the dark: how general processes of disinhibition produce both prosocial and antisocial behavior. Perspect. Psychol. Sci. 6, 415-427. doi: $10.1177 / 1745691611416992$

Hsee, C. K., Hatfield, E., Carlson, J. G., and Chemtob, C. (1990). The effect of power on susceptibility to emotional contagion. Cogn. Emot. 4, 327-340. doi: 10.1080/02699939008408081

Ickes, W. J. (1997). Empathic Accuracy. New York, NY: Guilford Press.

Keltner, D., Gruenfeld, D. H., and Anderson, A. (2003). Power, approach, and inhibition. Psychol. Rev. 110, 265-284. doi: 10.1037/0033-295X.110.2.265

Kilner, J. M. (2011). More than one pathway to action understanding. Trends Cogn. Sci. 15, 352-357. doi: 10.1016/j.tics.2011.06.005

Kunstman, J. W., and Maner, J. K. (2011). Sexual overperception: power, mating motives, and biases in social judgment. J. Pers. Soc. Psychol. 100, 282-294. doi: 10.1037/ a0021135

Lammers, J., Galinsky, A. D., Gordijn, E. H., and Otten, S. (2012). Power increases social distance. Soc. Psychol. Pers. Sci. 3, 282-290. doi: $10.1177 / 1948550611418679$

Lanzetta, J. T., and Englis, B. G. (1989). Expectations of cooperation and competition and their 
effects on observers' vicarious emotional responses. J. Pers. Soc. Psychol. 56, 543-554. doi: 10.1037/00223514.56.4.543

Liberman, N., and Trope, Y. (1998). The role of feasibility and desirability considerations in near and distant future decisions: a test of temporal construal theory. J. Pers. Soc. Psychol. 75, 5-18. doi: 10.1037/0022-3514.75.1.5

Liberman, N., Trope, Y., and Stephan, E. (2007). "Psychological distance," in Social Psychology: Handbook of Basic Principles, 2nd Edn., eds A. W. Kruglanski and E. T. Higgins (New York, NY: Guilford Press), 353-381.

Lieberman, M. D. (2010). "Social cognitive neuroscience," in Handbook of Social Psychology 5th edn., eds S. T. Fiske, D. T. Gilbert, and G. Lindzey (New York, NY: McGraw-Hill), 143-193.

Likowski, K. U., Weyers, P., Seibt, B., Stöhr, C., Pauli, P., and Mühlberger, A. (2011). Sad and lonely? sad mood suppresses facial mimicry. J. Nonverbal Behav. 35, 101-117. doi: 10.1007/s10919-011-0107-4

Lippa, R., and Arad, S. (1999). Gender, personality, and prejudice: the display of authoritarianism and social dominance in interviews with college men and women. J. Res. Pers. 33, 463-493. doi: 10.1006/jrpe.1999.2266

Magee, J. C., and Smith, P. K. (2013). The social distance theory of power. Pers. Soc. Psychol. Rev. 17, 158-186. doi: 10.1177/1088868312472732

Mitchell, J. P., Macrae, C. N., and Banaji, M. R. (2006). Dissociable medial prefrontal contributions to judgments of similar and dissimilar others. Neuron 50, 655-663. doi: 10.1016/j.neuron.2006.03.040

Morelli, S. A., Rameson, L. T., and Lieberman, M. D. (2012). The neural components of empathy: predicting daily prosocial behavior. Soc. Cogn. Affect. Neurosci. doi: 10.1093/scan/nss088

Mumenthaler, C., and Sander, D. (2012). Social appraisal influences recognition of emotions. J. Pers. Soc. Psychol. 102, 1118-1135. doi: 10.1037/a0026885

Muscatell, K. A., Morelli, S. A., Falk, E. B., Way, B. M., Pfeifer, J. H., Galinsky, A. D., et al. (2012). Social status modulates neural activity in the mentalizing network. Neuroimage 60, 1771-1777. doi: 10.1016/j.neuroimage.2012.01.080

Neal, D. T., and Chartrand, T. L. (2011). Embodied emotion perception: amplifying and dampening facial feedback modulates emotion perception accuracy. Soc. Psychol. Pers. Sci. 2, 673-678. doi: $10.1177 / 1948550611406138$

Niedenthal, P. M., Mermillod, M., Maringer, M., and Hess, U. (2010). The Simulation of Smiles (SIMS) model: embodied simulation and the meaning of facial expression. Behav. Brain Sci. 33, 417-433. discussion: 433-480. doi: 10.1017/S0140525X10000865

Oberman, L. M., Winkielman, P., and Ramachandran, V. S. (2007). Face to face: blocking facial mimicry can selectively impair recognition of emotional expressions. Soc. Neurosci. 2, 167-178. doi: 10.1080/17470910701391943

Rives Bogart, K., and Matsumoto, D. (2010). Facial mimicry is not necessary to recognize emotion: facial expression recognition by people with Moebius syndrome. Soc. Neurosci. 5, 241-251. doi: 10.1080/17470910903395692

Rosset, D. B., Rondan, C., Da Fonseca, D., Santos, A., Assouline, B., and Deruelle, C. (2008). Typical emotion processing for cartoon but not for real faces in children with autistic spectrum disorders. J. Autism Dev. Disord. 38, 919-925. doi: 10.1007/s10803-007-0465-2

Sander, D., Grandjean, D., Kaiser, S., Wehrle, T., and Scherer, K. R. (2007). Interaction effects of perceived gaze direction and dynamic facial expression: evidence for appraisal theories of emotion. Eur. J. Cogn. Psychol. 19, 470-480. doi: 10.1080/09541440600757426

Sato, W., Fujimura, T., Kochiyama, T., and Suzuki, N. (2013). Relationships among facial mimicry, emotional experience, and emotion recognition. PLOS ONE 8:e57889. doi: 10.1371/journal.pone.0057889

Schmid Mast, M. (2002). Dominance as expressed and inferred through speaking time: a metaanalysis. Hum. Commun. Res. 28, 420-450.

Schmid Mast, M., Jonas, K., Cronauer, C. K., and Darioly, A. (2012). On the importance of the superior's interpersonal sensitivity for good leadership. J. Appl. Soc. Psychol. 42, 1043-1068. doi: 10.1111/j.15591816.2011.00852.x

Schmid Mast, M., Jonas, K., and Hall, J. A. (2009). Give a person power and he or she will show interpersonal sensitivity: the phenomenon and its why and when. J. Pers. Soc. Psychol. 97, 835-850. doi: 10.1037/a0016234
Schultheiss, O. C., and Hale, J. A. (2007). Implicit motives modulate attentional orienting to perceived facial expressions of emotion. Motiv. Emot. 31, 13-24. doi: 10.1007/s11031-006-9042-9

Schultheiss, O. C., Wirth, M. M., Waugh, C. E., Stanton, S. J., Meier, E. A., and Reuter-Lorenz, P. (2008). Exploring the motivational brain: effects of implicit power motivation on brain activation in response to facial expressions of emotion. Soc. Cogn. Affect. Neurosci. 3, 333-343. doi: 10.1093/scan/nsn030

Sidanius, J., Pratto, F., van Laar, C., and Levin, S. (2004). Social dominance theory: its agenda and method. Polit. Psychol. 25, 845-880. doi: $\quad 10.1111 /$ j.1467-9221.2004. 00401.x

Snodgrass, S. E. (1985). Women's intuition: the effect of subordinate role on interpersonal sensitivity. $J$. Pers. Soc. Psychol. 49, 146-155. doi: 10.1037/0022-3514.49.1.146

Snodgrass, S. E. (1992). Further effects of role versus gender on interpersonal sensitivity. J. Pers. Soc. Psychol. 62, 154-158. doi: 10.1037/00223514.62.1.154

Snodgrass, S. E., Hecht, M. A., and Ploutz-Snyder, R. (1998). Interpersonal sensitivity: expressivity or perceptivity? J. Pers. Soc. Psychol. 74, 238-249. doi: 10.1037/0022-3514.74.1.238

Spunt, R. P., and Lieberman, M. D. (2012). An integrative model of the neural systems supporting the comprehension of observed emotional behavior. Neuroimage 59, 3050-3059. doi: 10.1016/j.neuroimage.2011.10.005

Spunt, R. P., Satpute, A. B., and Lieberman, M. D. (2011). Identifying the what, why, and how of an observed action: an fMRI study of mentalizing and mechanizing during action observation. J. Cogn. Neurosci. 23, 63-74. doi: 10.1162/jocn.2010.21446

Stevens, L. E., and Fiske, S. T. (2000). Motivated impressions of a powerholder: accuracy under task dependency and misperception under evaluation dependency. Pers. Soc. Psychol. Bull. 26, 907-922. doi: $10.1177 / 01461672002610002$

Uljarevic, M., and Hamilton, A. (2013). Recognition of emotions in autism: a formal meta-analysis. J. Autism Dev. Disord. 43, 1517-1526. doi: 10.1007/s10803-012-1695-5

van Baaren, R., Janssen, L., Chartrand, T. L., and Dijksterhuis, A. (2009). Where is the love? The social aspects of mimicry. Philos. Trans. R. Soc. B Biol. Sci. 364, 2381-2389. doi: 10.1098/rstb.2009.0057

Wang, J., Liu, L., and Zheng, Y. (2011). Effects of implicit power motive on the processing of anger faces: an event-related potential study. J. Res. Pers. 45, 441-447. doi: 10.1016/j.jrp.2011.05.004

Weyers, P., Muhlberger, A., Kund, A., Hess, U., and Pauli, P. (2009). Modulation of facial reactions to avatar emotional faces by nonconscious competition priming. Psychophysiology 46, 328-335. doi: 10.1111/j.1469-8986.2008.00771.x

Winter, D. G. (1973). The Power Motive New York, NY: Free Press.

Zaki, J., Bolger, N., and Ochsner, K. (2009). Unpacking the informational bases of empathic accuracy. Emotion 9, 478-487. doi: 10.1037/a0016551

Zaki, J., and Ochsner, K. (2012). The neuroscience of empathy: progress, pitfalls and promise. Nat. Neurosci. 15, 675-680. doi: 10.1038/ nn.3085

Zaki, J., Weber, J., Bolger, N., and Ochsner, K. (2009). The neural bases of empathic accuracy. Proc. Natl. Acad. Sci. U.S.A. 106, 11382-11387. doi: 10.1073/pnas.0902666106

Zebrowitz, L. A. (2001). "Groping for the elephant of interpersonal sensitivity," in Interpersonal Sensitivity: Theory and Measurement, eds J. A. Hall and F. J. Bernieri (Mahwah, NJ: Lawrence Erlbaum Associates), 333-350.

Conflict of Interest Statement: The authors declare that the research was conducted in the absence of any commercial or financial relationships that could be construed as a potential conflict of interest.

Received: 01 May 2013; accepted: 28 June 2013; published online: 19 July 2013. Citation: Bombari D, Schmid Mast M, Brosch T and Sander D (2013) How interpersonal power affects empathic accuracy: differential roles of mentalizing vs. mirroring? Front. Hum. Neurosci. 7:375. doi: 10.3389/fnhum.2013.00375 Copyright (c) 2013 Bombari, Schmid Mast, Brosch and Sander. This is an open-access article distributed under the terms of the Creative Commons Attribution License, which permits use, distribution and reproduction in other forums, provided the original authors and source are credited and subject to any copyright notices concerning any thirdparty graphics etc. 